\title{
Tephra layers in the Dome Fuji (Antarctica) deep ice core
}

\author{
Y. Fujiı, ${ }^{1}$ M. Kohno, ${ }^{1}$ H. Motoyama, ${ }^{1}$ S. Matoba, ${ }^{1}$ O. Watanabe, ${ }^{1}$ S. Fujita, ${ }^{2}$ N. Azuma, ${ }^{3}$ \\ T. Kikuchi, ${ }^{4}$ T. Fukuoka, ${ }^{5}$ T. Suzuki, ${ }^{6}$ \\ ${ }^{1}$ National Institute of Polar Research, Itabashi-ku, Tokyo 173-8515, Japan \\ ${ }^{2}$ Department of Applied Physics, Hokkaido University, Sapporo, Hokkaido 060-8628, Japan \\ ${ }^{3}$ National Nagaoka College of Technology, Nagaoka, Niigata 940-0817, Japan \\ ${ }^{4}$ Science University of Tokyo in Yamaguchi, Onoda, Yamaguchi 756-0884, Japan \\ ${ }^{5}$ Faculty of Geo-Environmental Science, Rissho University, Kumagaya, Saitama 360-0194, Japan \\ ${ }^{6}$ Faculty of Science, Yamagata University, Yamagata 990-0021, Japan
}

\begin{abstract}
A deep ice core drilled to $2503 \mathrm{~m}$ depth at Dome Fuji, Antarctica, contains 25 visible tephra layers during the past $340 \mathrm{ka}$. The thickness of tephra layers is in the range $1-24 \mathrm{~mm}$. The thickness and duration at deposition, determined by a simple iceflow model, suggests that a violent volcanic eruption caused ash to fall onto the Antarctic ice sheet for $\sim 5$ years and to form a $\sim 100 \mathrm{~mm}$ thick tephra layer at $117 \mathrm{ka}$ BP. Two tephra layers at depths of 573 and $2202 \mathrm{~m}$ probably originated from volcanoes in the South Sandwich Islands, Southern Ocean, given the size of tephra shards, $>20 \mu \mathrm{m}$ in diameter, and their major chemical composition. Only eight of the 25 tephra layers can also be recognized in the Vostok (Antarctica) ice core, but all correspond to the Vostok tephras if we consider cloudy bands to be volcanic.
\end{abstract}

\section{INTRODUCTION}

Explosive volcanic eruptions eject huge amounts of dust and gases into the atmosphere. The far-traveled volcanic aerosols in the atmosphere eventually settle to the ice sheet, forming a tephra layer or an acidic layer in the fallen snow. Ice cores from polar regions, therefore, provide a detailed record of local and distal volcanic eruptions. Though recent ice-core studies have clarified volcanic chronology (e.g. Legrand and Delmas, 1987; Delmas and others, 1992; Cole-Dai and others, 1997) and its relation to climate change (e.g. Hammer and others, 1980; Palais and Sigurdsson, 1989), only limited studies have been done on volcanic activities back to the last glacial period (e.g. Zielinski and others, 1996; Hammer and others, 1997).

The present study reveals tephra layers found in a $2503 \mathrm{~m}$ deep ice core from Dome Fuji, Antarctica (Dome-F Deep Coring Group, 1999), spanning three glacial-interglacial cycles of the last $340 \mathrm{ka}$ (Watanabe and others, 1999).

\section{TEPHRA LAYERS}

Stratigraphic observation was carefully carried out at Dome Fuji station and the home cold laboratory. We found two kinds of stratigraphical features: one is a "cloudy band" of light-gray color without color gradation in the band; the other is a "tephra layer", recognized because of features such as yellowish or brown color, shade in color and/or visible particles under a $30 \times$ magnifying glass.

We found 821 cloudy bands in total. There are three cloudy-band zones in the depth ranges 480-715, 940-1130 and $1760-2050 \mathrm{~m}$. Numbers of cloudy bands found in these zones are 311, 155 and 297, respectively. A few cloudy bands are found at other depths. We have not examined the particles yet, but some of them are likely to be volcanic because
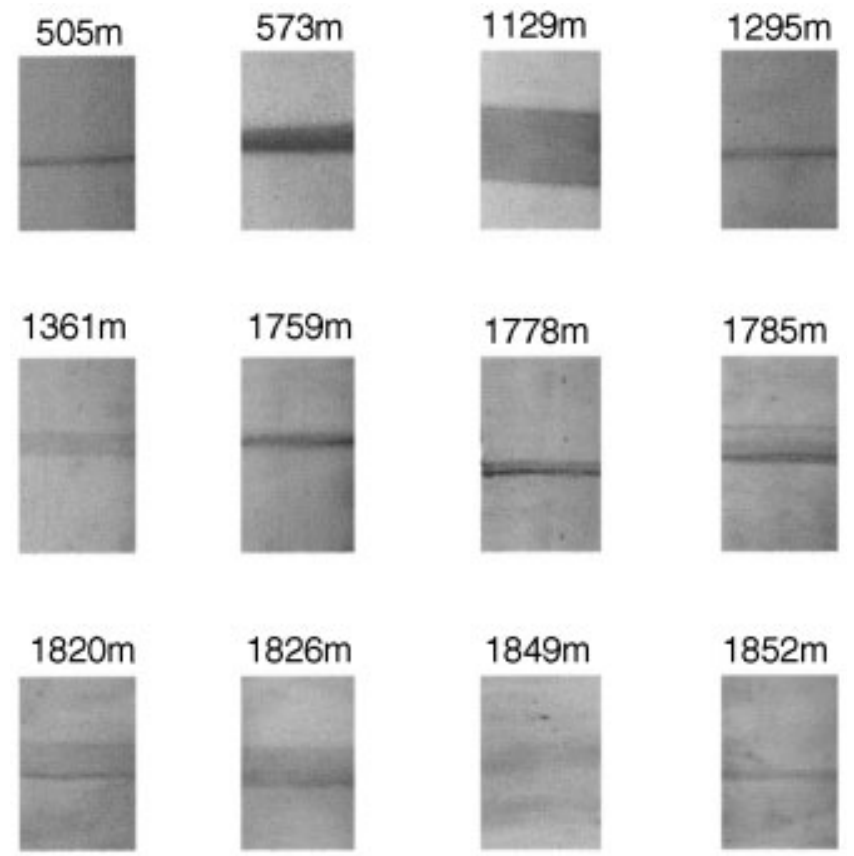

$1849 m$

$1852 m$
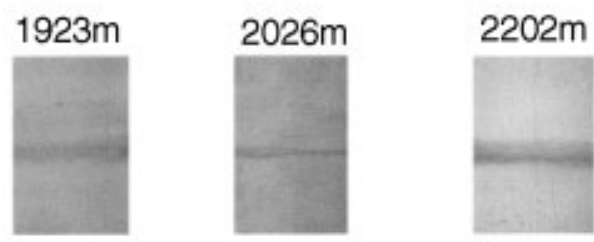

$2263 m$

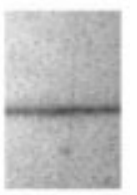

top

$20 \mathrm{~mm}$

Fig. 1. Sixteen examples of tephra layers found in a 2503 m deep Dome Fuji ice core. 


\begin{tabular}{|c|c|c|c|c|c|c|c|}
\hline \multirow[t]{3}{*}{ No. } & \multirow{3}{*}{$\begin{array}{c}\text { Depth } \\
\text { m }\end{array}$} & \multirow{3}{*}{$\begin{array}{l}\text { Age } \\
\text { ka BP }\end{array}$} & \multirow{3}{*}{$\begin{array}{c}\text { Thickness } \\
\text { mm }\end{array}$} & \multirow{3}{*}{$\begin{array}{c}\text { Initial thickness } \\
\text { mm }\end{array}$} & \multirow{3}{*}{$\begin{array}{l}\text { Fallout duration } \\
\qquad \begin{array}{l}\text { a }\end{array}\end{array}$} & \multicolumn{2}{|c|}{ Stratigraphic observation } \\
\hline & & & & & & Colour & Features \\
\hline & & & & & & & \\
\hline 1 & 505.80 & 14 & 2 & 2 & 0.1 & Dark grayish yellow & Particles \\
\hline 2 & 573.87 & 18 & 8 & 10 & 0.5 & Dull yellow & \\
\hline 3 & 1113.63 & 53 & 2 & 4 & 0.2 & Grayish yellow & \\
\hline 4 & 1128.48 & 54 & 12 & 22 & 1.0 & Pale yellow & \\
\hline 5 & 1129.46 & 54 & 21 & 39 & 1.8 & Yellowish brown & Particles \\
\hline 6 & 1295.22 & 66 & 3 & 6 & 0.2 & Light gray & Particles \\
\hline 7 & 1336.45 & 70 & 4 & 9 & 0.3 & Light gray & Shade, particles \\
\hline 8 & 1361.89 & 72 & 8 & 18 & 0.6 & Light gray & \\
\hline 9 & 1426.45 & 77 & 6 & 14 & 0.5 & Light gray & Shade, particles \\
\hline 10 & 1499.84 & 83 & 3 & 8 & 0.3 & Light gray & Shade \\
\hline 11 & 1568.41 & 90 & 4 & 11 & 0.5 & Light gray & Shade \\
\hline 12 & 1759.12 & 106 & 4 & 14 & 0.2 & Grayish yellow & Shade, particles \\
\hline 13 & 1778.88 & 107 & 4 & 15 & 0.2 & Grayish yellow & Shade, particles \\
\hline 14 & 1785.14 & 107 & 13 & 49 & 1.0 & Light gray & Shade, particles \\
\hline 15 & 1818.51 & 111 & 11 & 43 & 1.7 & Grayish yellow & Particles \\
\hline 16 & 1820.92 & 112 & 9 & 35 & 1.6 & Light gray & Shade, particles \\
\hline 17 & 1826.49 & 113 & 10 & 40 & 1.7 & Light gray & Shade, particles \\
\hline 18 & 1849.55 & 117 & 24 & 98 & 4.9 & Light gray & Particles \\
\hline 19 & 1852.26 & 117 & 5 & 21 & 0.9 & Light gray & \\
\hline 20 & 1923.31 & 132 & 5 & 23 & 1.1 & Dull yellow & Particles \\
\hline 21 & 2026.34 & 154 & 1 & 6 & 0.2 & Grayish yellow & Particles \\
\hline 22 & 2117.75 & 176 & 2 & 14 & 0.4 & Light yellow & \\
\hline 23 & 2170.18 & 189 & 2 & 16 & 0.4 & Light gray & Particles \\
\hline 24 & 2202.81 & 196 & 8 & 68 & 2.2 & Light gray & Particles \\
\hline 25 & 2263.12 & 217 & 3 & 29 & 0.9 & Dull yellow & Particles \\
\hline
\end{tabular}

the upper cloudy-band zone covering the Last Glacial Maximum corresponds to the 2000 cloudy bands, composed mainly of glassy and crystalline fragments of $<5 \mu \mathrm{m}$ diameter, in the Byrd ice core deposited during 15-17 ka BP (Gow and Williamson, 1971).

We found 25 tephra layers by continuous stratigraphic observation. Figure 1 shows photos of 16 tephra layers as examples. Some of the layers have a uniform shade of color, suggesting continuous fallout of tephra ejected to the stratosphere. Tephra layers with distinct shade of color at the lower boundary were probably due to tephra fallout through the stratosphere from the source volcano following fallout through the troposphere. The tephra layers at 1778 and $1785 \mathrm{~m}$ depth are double-layered with a thicker, darker layer at the bottom. The double-layered tephras are considered to indicate repeated eruptions from a volcano.

Table 1 shows a list of tephra layers. Ages of tephra layers are calculated by using the relation between the $\delta^{18} \mathrm{O}$ value of snow in the area with $\delta^{18} \mathrm{O} \geq_{-}-51$ per mil in east Dronning Maud Land and a simple steady-state ice-flow model proposed by Dansgaard and Johnsen (1969) (Watanabe and others, 1999). The chronological accuracy for this time-scale calculation could be estimated as about $20 \%$ for long-term variations. The thickness of the tephra layers is in the range 1-24 mm. The initial thickness of the tephra layers at their formation on the ice-sheet surface, estimated by using the steady-state model, is shown in Table 1. The duration of tephra fallout onto the ice sheet is also calculated.

Figure 2 shows the vertical distributions of actual and initial tephra thickness and duration of tephra fallout. The median tephra thickness is $15 \mathrm{~mm}$, which corresponds to the median fallout duration of 1.5 years.

The thickest tephra layer at $1849 \mathrm{~m}$ depth is $98 \mathrm{~mm}$ thick and took about 5 years to be deposited on the ice-sheet surface. Since the residence time of stratospheric aerosols is about 1.5 years, as estimated from the decrease in the nuclear bomb radioactivity of snow in Antarctica (Pourchet and others, 1983), the duration of the eruption which caused the $98 \mathrm{~mm}$ thick tephra layer at Dome Fuji $117 \mathrm{ka}$ BP is thought to have lasted and kept ejecting a large amount of tephra into the atmosphere for $>3$ years.

\section{COMPARISON WITH VOSTOK IGE CORE}

More than 30 tephra layers were found in the $3 \mathrm{G}, 3 \mathrm{G} 1,4 \mathrm{G} 2$, 5G, 5Gl and BH Vostok (Antarctica) ice cores (Basile, 1997). To correlate tephra layers in the Dome Fuji and Vostok ice cores, we superimpose the oxygen and hydrogen stable-isotope ratio on the vertical tephra distributions of the Dome Fuji and Vostok ice cores, respectively, as shown in Figure 3. Judging from the position of each tephra layer on the isotope profiles, eight tephra layers, located at depths of 505, 1128 or 1129, 1362, 1568, 1850, 2026, 2118 and $2170 \mathrm{~m}$ in the Dome Fuji ice core probably correspond to those at depths of 369, 945, 1279, 1508 or 1510, 1995, 2287, 2325 and 2498 m, respectively, in the Vostok ice core.

The tephra layer at $1849 \mathrm{~m}$ depth in the Dome Fuji ice core is the thickest, at $24 \mathrm{~mm}$ thick; the corresponding layer at $1996 \mathrm{~m}$ depth in the Vostok ice core has a similar thickness, $20 \mathrm{~mm}$. The source volcano of the Vostok tephra layer is considered to be Mount Berlin in Marie Byrd Land on the basis of the chemical composition (Basile, 1997). The age of the tephra layer at $1849 \mathrm{~m}$ depth, $117 \mathrm{ka} \mathrm{BP}$, is different from that of the corresponding Vostok layer at 1996 m, $142 \mathrm{ka}$ BP, 


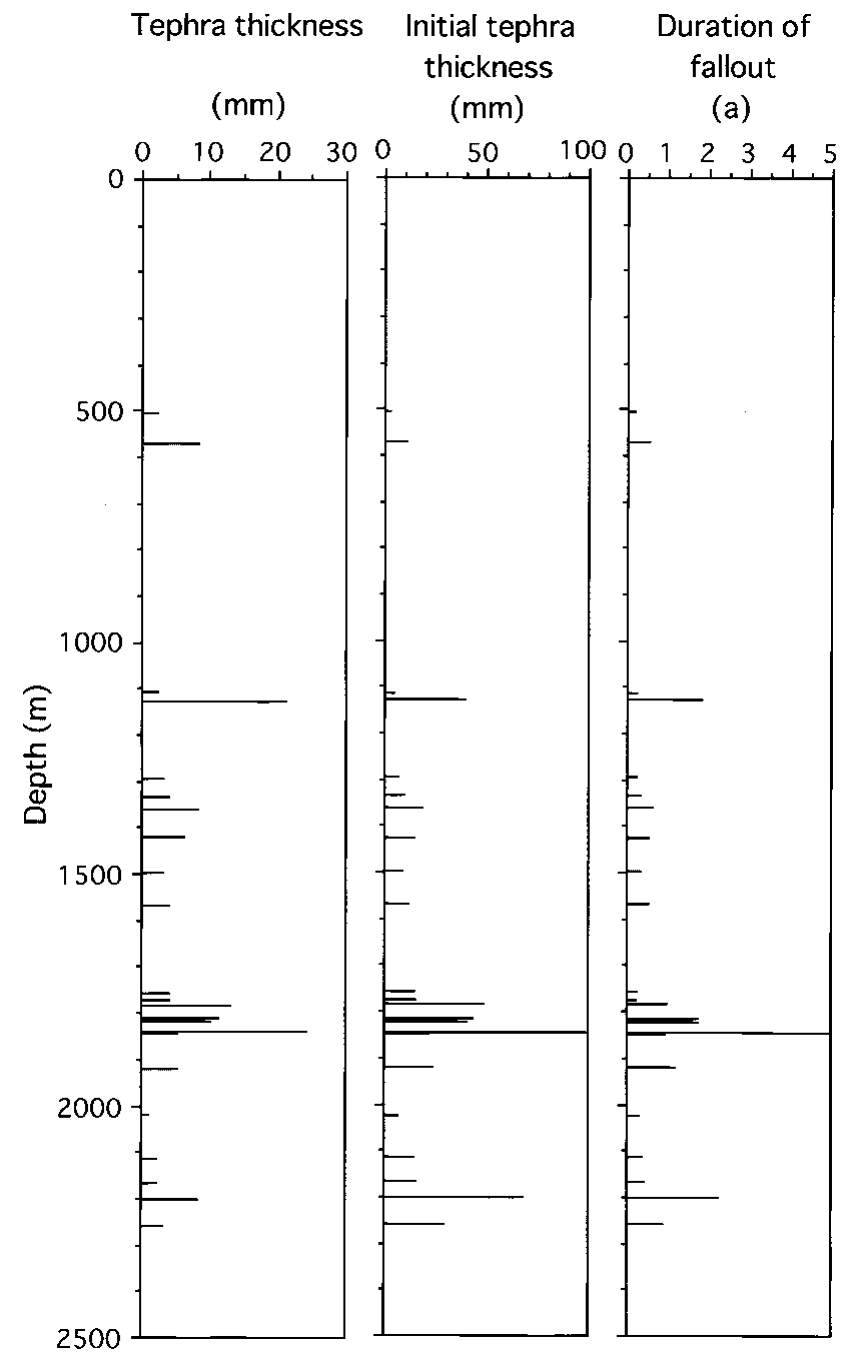

Fig. 2. Vertical distributions of actual and initial thicknesses, and fallout durations of 25 tephra layers.

which shows good agreement with the ${ }^{40} \mathrm{~A} /{ }^{39} \mathrm{~A}$ age of volcanic ash of Mount Berlin, 141 ka BP (Basile, 1997).

There are some probable reasons for a limited correspondence between tephra layers in Dome Fuji and Vostok ice cores. One of these is the absence of snow layers after tephra deposition due to the erosion of surface snow by strong wind. But if we consider the cloudy bands in the Dome Fuji ice cores as being of volcanic origin, most of the Dome Fuji tephra layers correspond to Vostok layers.

\section{CHEMICAL GOMPOSITION}

We determined chemical compositions of glass shards which were found in two specific tephra layers at depths of 573 and $2202 \mathrm{~m}$ (Table 1). Ages of these layers are estimated to be $\sim 18$ and $\sim 196 \mathrm{ka} \mathrm{BP}$, respectively. Both layers are $8 \mathrm{~mm}$ thick, but the estimated durations of deposition are $\sim 0.5$ and $\sim 2.2$ years, respectively. The 573 m layer is yellowish-brown and the $2202 \mathrm{~m}$ layer is pale-yellowish.

Scanning electron microphotographs (SEMs) of glass shards from the 573 and $2202 \mathrm{~m}$ layers, whose average sizes are $20-50 \mu \mathrm{m}$, are shown in Figure 4 . The grain-size suggests that the source volcanoes are located in and around Antarctica. The $573 \mathrm{~m}$ tephra is commonly blocky and poor in vesicularity (Fig. 4a). It shows pilotaxitic texture. It is

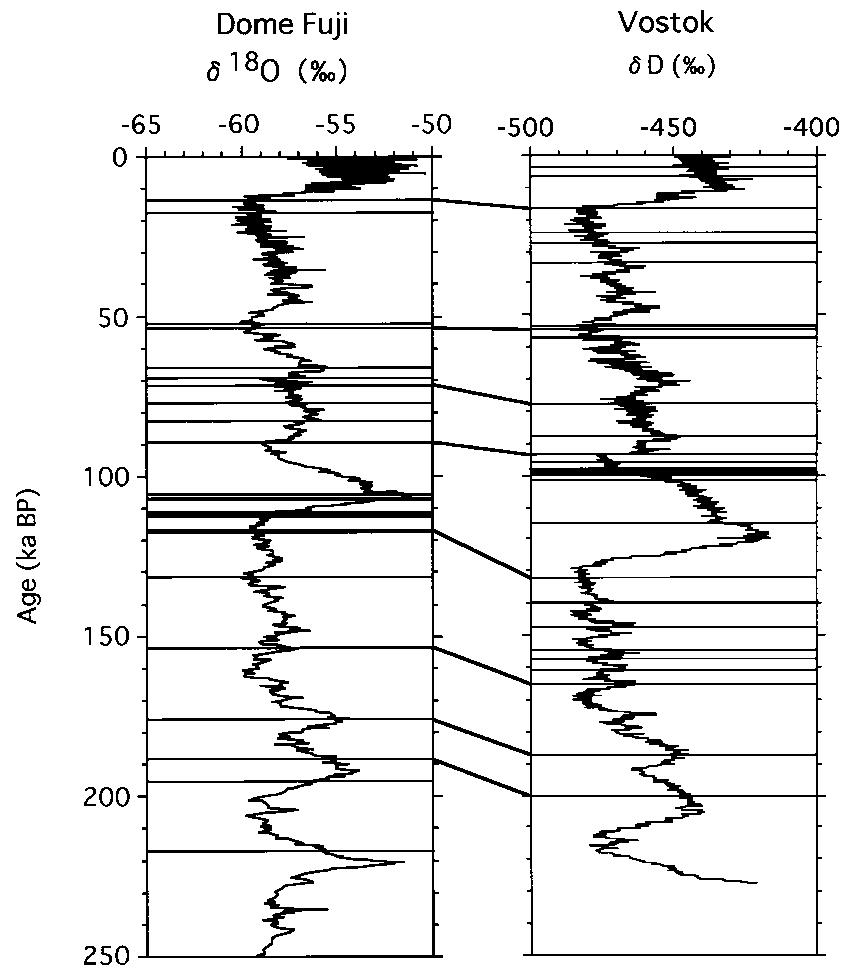

Fig. 3. Correspondence of Dome Fuji tephra layers with those in the Vostok ice core based on the tephra positions on oxygen and hydrogen stable-isotope profiles, respectively. Only eight tephra layers found in both ice cores correspond.
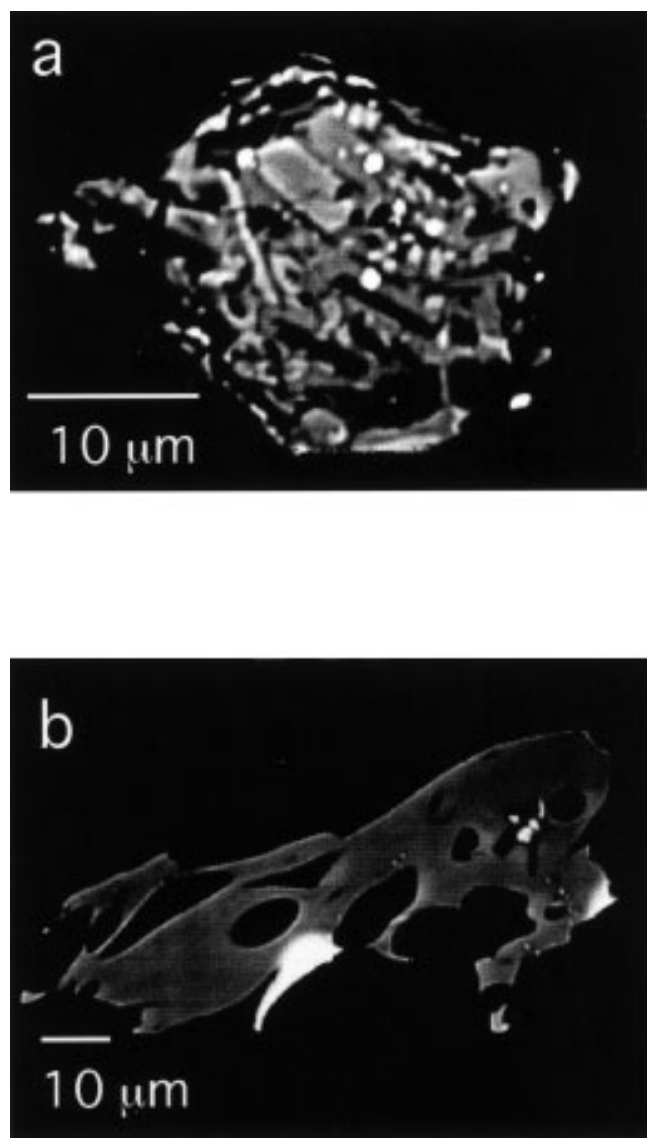

Fig. 4. SEMs of thin sections of tephras from layers at depths of ( a ) $573 \mathrm{~m}$ and (b) $2202 \mathrm{~m}$. 
Table 2. Chemical compositions of tephras from layers at depths of 573 and $2202 \mathrm{~m}$
Oxide

$$
573 \text { m tephra }
$$$$
\text { wt. } \%
$$
$2202 m$ tephra
wt. $\%$

\begin{tabular}{|c|c|c|c|c|}
\hline $\mathrm{SlO}_{2}$ & 55.25 & $(0.54)$ & 64.78 & $(0.52)$ \\
\hline $\mathrm{TiO}_{2}$ & 1.12 & $(0.15)$ & 0.79 & $(0.04)$ \\
\hline $\mathrm{Al}_{2} \mathrm{O}_{3}$ & 13.92 & $(0.65)$ & 14.52 & $(0.20)$ \\
\hline $\mathrm{FeO}^{*}$ & 13.11 & $(1.39)$ & 7.19 & (0.15) \\
\hline $\mathrm{MnO}$ & 0.24 & $(0.05)$ & 0.19 & $(0.03)$ \\
\hline $\mathrm{MgO}$ & 4.18 & (0.48) & 1.64 & $(0.12)$ \\
\hline $\mathrm{CaO}$ & 8.04 & $(0.40)$ & 5.07 & (0.14) \\
\hline $\mathrm{Na}_{2} \mathrm{O}$ & 2.31 & $(0.31)$ & 4.63 & $(0.16)$ \\
\hline $\mathrm{K}_{2} \mathrm{O}$ & 0.22 & $(0.04)$ & 0.82 & $(0.04)$ \\
\hline Total & 98.39 & & 99.62 & \\
\hline$n$ & 4 & & 4 & \\
\hline
\end{tabular}

${ }^{*}$ Total $\mathrm{Fe}$ as $\mathrm{FeO}$.

Notes: $n$, number of analyses. Numbers in parentheses express $1 \sigma$ (one standard deviation).

composed of euhedral microphenocryst and subhedral microlite, which are commonly plagioclase, pyroxene and opaque minerals, with a minor quantity of interstitial glass. The $2202 \mathrm{~m}$ tephra is glassy and moderately vesiculated (Fig. 4b). It shows fluidal morphology.

Major element compositions of tephras, including $\mathrm{SiO}_{2}$, $\mathrm{TiO}_{2}, \mathrm{Al}_{2} \mathrm{O}_{3}, \mathrm{FeO}, \mathrm{MnO}, \mathrm{MgO}, \mathrm{CaO}, \mathrm{Na}_{2} \mathrm{O}$ and $\mathrm{K}_{2} \mathrm{O}$, were determined using a JEOL-JXA8800 wavelength-dispersive electron microprobe analyzer with the ZAF correction method. The tephras were analyzed with accelerating voltage of $15 \mathrm{keV}$ and electron-beam current of $12 \mathrm{nA}$. The electron-beam diameter was set at $>5 \mu \mathrm{m}$ to minimize migration of sodium during the analysis. The $573 \mathrm{~m}$ tephra was analyzed with a broad electron-beam $(10-15 \mu \mathrm{m})$ in order to obtain an average chemical composition of groundmass without microphenocrysts. The accuracy and precision of the analyses were checked by repeated analyses of glass and mineral standards.

Mean chemical compositions of the tephras are shown in Table 2. The compositions (andesitic and dacitic poor in $\mathrm{K}_{2} \mathrm{O}$, respectively) are typical of subduction volcanism. The $573 \mathrm{~m}$ tephra is basaltic andesite. The tephra is similar in composition to aphiric basaltic andesite from Visoko Island in the South Sandwich Islands, Southern Ocean (Baker, 1978). The $2202 \mathrm{~m}$ tephra is homogeneous dacitic glass. This is similar in composition to aphyric dacitic lava from the northern part of Candlemas Island in the South Sandwich Islands (Baker, 1978; Tomblin, 1979).

It is inferred that both the 573 and $2202 \mathrm{~m}$ tephras originated from volcanoes in the South Sandwich Islands, which are about $3000 \mathrm{~km}$ from Dome Fuji. Glass shards, whose source is considered to be the South Sandwich Islands, were found in ice cores from Mizuho (Higashi and Fujii, 1994) and Vostok stations (Palais and others, 1987) and in bare-ice areas near the Yamato (Katsushima and others, 1984; Nishio and others, 1985) and Sør Rondane Mountains (Naraoka and others, 1991), Dronning Maud Land. This suggests that tephra dusts from the South Sandwich Islands were widely dispersed onto the East Antarctic ice sheet through the atmospheric transport paths proposed by Carleton (1981) and Thompson and Mosley-Thompson (1982), and supports our results.

\section{CONGLUSIONS}

We found 25 tephra layers, which have the features of yellowish or brown color, shade in color or visible particles under a magnifying glass, in a Dome Fuji deep ice core. The median thickness at deposition onto the surface is $15 \mathrm{~mm}$, which corresponds to a median fallout duration of 1.5 years. The thickest tephra layer, at $1849 \mathrm{~m}$ depth, is $98 \mathrm{~mm}$ in initial thickness and took about 5 years to be deposited onto the ice-sheet surface.

Two tephra layers at depths of 573 and $2202 \mathrm{~m}$ are thought to have originated from the South Sandwich Islands, given the size of tephra shards, $>20 \mu \mathrm{m}$ in diameter, and their major chemical composition. Based on preliminary morphological observation by scanning electron microscope, the tephra layer at $1361 \mathrm{~m}$ depth is composed of glassy shards $>20 \mu \mathrm{m}$ in diameter, suggesting local volcanic origin. The thickest tephra layer at $1849 \mathrm{~m}$ depth corresponds to the tephra layer with a similar thickness of $20 \mathrm{~mm}$ at $1996 \mathrm{~m}$ depth in the Vostok ice core. The source volcano of the tephra layer is considered to be Mount Berlin, Marie Byrd Land. These facts suggest that the tephra layers in the Dome Fuji ice core are due to volcanism in and around Antarctica.

Among the 25 tephra layers, only eight correspond to the Vostok layers, judging from the position of each tephra layer on the Dome Fuji and Vostok isotope profiles. But if we consider the cloudy bands to be of volcanic origin, all of the Dome Fuji tephra layers correspond to Vostok layers. This suggests that some of the cloudy bands found at $821 \mathrm{~m}$ depth, concentrated in the depth ranges 480-715, 940-1130 and $1760-2050 \mathrm{~m}$, are possibly of volcanic origin.

The age of the tephra layer at $1849 \mathrm{~m}$ depth, $117 \mathrm{ka}$ BP, is different from that of the corresponding Vostok layer at $1996 \mathrm{~m}, 142 \mathrm{ka}$ BP, which shows good agreement with the ${ }^{40} \mathrm{~A} /{ }^{39} \mathrm{~A}$ age of volcanic ash of Mount Berlin, $141 \mathrm{ka}$ BP. This suggests that the chronological accuracy for Dome Fuji time-scale calculation could be estimated as about $20 \%$ for long-term variations.

\section{ACKNOWLEDGEMENTS}

We would like to express our hearty thanks to the wintering members of the Japanese Antarctic Research Expeditions who gave us extraordinary support for the Dome Fuji Project during 1991-97. Special thanks go to R. J. Delmas of the Laboratoire de Glaciologie et Géophysique de l'Environnement, Grenoble, France, for providing valuable comments and the doctoral thesis of I. Basile.

\section{REFERENCES}

Baker, P. E. 1978. The South Sandwich Islands: III. Petrology of the volcanic rocks. Br. Antarct. Surv. Sci. Rep. 93, 1-34.

Basile, I. 1997. Origine des aérosols volcaniques et continentaux de la carotte de glace de Vostok (Antarctique). (Thèse de doctorat, Université JosephFourier-Grenoble I.)

Carleton, A. M. 1981. Monthly variability of satellite-derived cyclone activity for the southern hemisphere winter. F. Climatol., 1, 21-38.

Cole-Dai, J., E. Mosley-Thompson and L. G. Thompson. 1997. Annually resolved Southern Hemisphere volcanic history from two Antarctic ice cores. F. Geophys. Res., 102(D14), 16,761-16,771.

Dansgaard, W. and S. J. Johnsen. 1969. A flow model and a time scale for the ice core from Camp Century, Greenland. 7. Glaciol., 8(53), 215-223.

Delmas, R. J., S. Kirchner, J. M. Palais and J. -R. Petit. 1992.1000 years of explosive volcanism recorded at the South Pole. Tellus, 44B (4), 335-350.

Dome-F Deep Coring Group. 1998. Deep ice-core drilling at Dome Fuji and glaciological studies in east Dronning Maud Land, Antarctica. Ann. 
Glaciol., 27, 333-337.

Gow, A. J. and T. Williamson. 1971. Volcanic ash in the Antarctic ice shee and its possible climatic implications. Earth Planet. Sci. Lett., 13(1), 210-218.

Hammer, C. U., H. B. Clausen and W. Dansgaard. 1980. Greenland ice sheet evidence of post-glacial volcanism and its climatic impact. Nature, 288(5788), 230-235.

Hammer, C. U., H. B. Clausen and C. C. Langway, Jr. 1997. 50,000 years of recorded global volcanism. Climatic Change, 35, 1-15.

Higashi, A. and Y. Fujii. 1994. Studies on microparticles contained in medium-depth ice cores retrieved from east Dronning Maud Land, Antarctica. Ann. Glaciol., 20, 73-79.

Katsushima, T., F. Nishio, H. Ohmae, M. Ishikawa and S. Takahashi. 1984. Composition of dirt layers in the bare ice areas near the Yamato Mountains in Queen Maud Land and the Allan Hills in Victoria Land, Antarctica. Natl. Inst. Polar Res. Mem., Special Issue 34, 174-187.

Legrand, M. R. and R. J. Delmas. 1987. A 220-year continuous record of volcanic $\mathrm{H}_{2} \mathrm{SO}_{4}$ in the Antarctic ice sheet. Nature, 327(6124), 671-676.

Naraoka, H., K. Yanai and S. Fujita. 1991. [Dirt bands in the bare ice area around Sør Rondane Mountains in Queen Maud Land, Antarctica.] Antarct. Rec., 35(1), 47-55. [InJapanese.]

Nishio, F., T. Katsushima and H. Ohmae. 1985. Volcanic ash layers in bare ice areas near the Yamato Mountains, Dronning Maud Land and the Allan Hills, Victoria Land, Antarctica. Ann. Glaciol., 7, 34-41.
Palais, J. M. and H. Sigurdsson. 1989. Petrologic evidence of volatile emissions from major historic and pre-historic volcanic eruptions. In Berger, A., R. E. Dickinson and J. Kidson, eds. Understanding climate change. Washington, DC, American Geophysical Union, 31-53. (Geophysical Monograph 52, IUGG Volume 7.)

Palais, J. M., E. Mosley-Thompson and E. Thomas. 1987. Correlation of a 3,200 year old tephra in ice cores from Vostok and South Pole stations, Antarctica. Geophys. Res. Lett., 14(8), 804-807.

Pourchet, M., J. F. Pinglot and C. Lorius. 1983. Some meteorological applications of radioactive fallout measurements in Antarctic snows. f. Geophys. Res., 88(C10), 6013-6020.

Thompson, L. G. and E. Mosley-Thompson. 1982. Spatial distribution of microparticles with Antarctic snow-fall. Ann. Glaciol., 3, 300-306.

Tomblin, J. F. 1979. The South Sandwich Islands: II. Geology of the Candlemas Island. Br. Antarct. Surv. Sci. Rep. 92, 1-33.

Watanabe, O., K. Kamiyama, H. Motoyama, Y. Fujii, H. Shoji and K. Satow. 1999. The paleoclimate record in the ice core at Dome Fuji station, East Antarctica. Ann. Glaciol., 29 (see paper in this volume).

Zielinski, G. A., P. A. Mayewski, L. D. Meeker, S. I. Whitlow and M. S. Twickler. 1996. 110,000-yr record of explosive volcanism from the GISP2 (Greenland) ice core. Quat. Res., 45(2), 109-118. 